\title{
An Exploration of Innovation of College Ideological and Political Education in New Era
}

\author{
Song Sumin; Li Lanyu; Li Likun \\ Institute of Political Science and Law, Xingtai University, Xingtai Hebei 054001
}

\begin{abstract}
With the changing of the time, China is gradually going towards a socialist market economy. At this critical period, information technology and knowledge economy will follow. Changes in the social environment also make people's thinking undergone tremendous change. In the re-establishment process of new ideas and culture, breaking the original balance and stability has provided an opportunity for the innovative ways of ideological and political education in colleges. However, new problems have generated as well. As for ideological and political education, colleges face a series of problems, among which, it is a top priority to properly deal with the ideological and political education. Based on these issues, this paper will propose some innovative ideas and measures of college ideological and political education in new era, such as changing of the concept of ideological and political education, getting rid of the traditional teaching mode, taking full advantage of the Internet and continue to build an excellent education base, strengthening the construction of ideological and political education team, and promotion of community education.
\end{abstract}

Keywords: ideological and political education; innovation; analysis

\section{The Situation of College Ideological and Political Education in New Era}

To begin with, under the influence of the socialist market economy, everything is done for the purpose of interest, which has caused some negative effects on the forming of the correct values of the college students. First, college students do not know much of socialist collectivism, as a result, they put personal interests ahead, ignoring the collective interests; second, since the existence of money worship and hedonism, college students appear to follow the negative phenomena. In addition, with the continuous development of society, social competition is increasingly fierce. A series of social problems brought confusion to the students, which makes their psychological stress gradually become larger. At the meantime, accompanied by mental setback, many students often show a lot of pessimism, depression and so on. As to the ideological and political education of the new era, mental health problems is an important part, however, in the traditional education, psychological problems are ignored, and the error has been contributed to ideological problems, which has ultimately make lots of college students have rebellious psychology. According to the data of recent years, the number of students suffering from mental illness or mental disorders is increasing, therefore, mental health education must be strengthened. Furthermore, with the development of information technology, a series of its negative effects are increasingly prominent.

The generation of the Internet has brought great changes to our lives, and the Internet plays an important part in the campus, along which it has also produced an unprecedented influence on ideological and political education of college students. Firstly, the network is a hypermedia, thus, during the formation of the views of world, life and values, college students are deeply influenced by the Internet. As a major factor of the Internet, hypermedia makes the Internet not be limited in time and space, and the Internet has a large and wide range of information and content, among which there is a large amount of bad information as well through reading which college students will make their views have some differences. Second, the network has hidden features, which will affect the cultivating of integrity. Such three characteristics of the Internet, as virtual, digital and hidden continue to affect people's lives. The rising of the Internet has made the direct interaction between people reduced. In the virtual network environment, more exchanges are between virtual identities. While communication among students becomes widespread, trust has also been a great challenge. Such negative thoughts as violence, money, seduction, sex, money, worship, etc. will mix in, which undoubtedly, present a great lure for those college students who have just entered the school, and for a long time will seriously affect the behavior of modern college students in our country.

\section{The Problems Facing College Ideological and Political Education in New Era}

\subsection{The Lack of Effectiveness on Methods and Contents of Ideological and Political Education}


First, as times are changing and society is improving, it will divorce from the reality to produce practical value to develop ideological and political education based still on Marxism-Leninism, Mao Zedong Thought and Deng Xiaoping Theory. Meanwhile, the traditional ideological and political education is mainly through indoctrination method, as a result, it only pays attention to the education of theoretical knowledge in class, while ignoring the corresponding practice, and the education content has not finally become the college students' own thoughts, which lead to ineffectiveness of such ideological and political education.

Second, China's moral education targets are still not realistic, and do not conform to the contemporary development. Based on the research findings, our current moral education goals correspond to the era of the old planned economy period. In the long-term implementation process, two typical characteristics have come into being. On the one hand, it is seriously modeling with a single goal, ignoring the student's personality. On the other hand, it is too idealistic, without considering the level of students' ethical standards, leading to the unrealistic high requirement to all the students. It has deviated from the moral objective, nor has it achieved the purpose of college ideological and political education, nor has it solved the real problems facing the students.

\subsection{Problems Existing in Ideological and Political Educators Group}

Generally speaking, the quality of the ideological and political education team is related to the results of our modern political education. According to the current situation, in terms of the college team of ideological and political education, there are still the following problems.

First, ideological and political education has not been attached importance to. The different statuses of the education staff cause the disparity in treatment, and there is still a prolonged assessment of the education personnel's titles, which makes it difficult for them to work in relief. Second, the ideological and political education team is not very stable. Many educators gradually transfer to other industries, and are not willing to engage in ideological and political education any longer. The third point is the generally low educational cadres. The focus is reflected in the low educated cadres, the lack of psychology and pedagogy professional teachers, and the old-fashioned management model of ideological and political education.

\subsection{Inadequate of Evaluation System of Ideological and Political Education}

According to the present situation, the ideological and political education in colleges has not yet fully equipped with simple, scientific, ease mechanisms and cannot effectively carry out inspection, supervision and management to the quality of ideological and political education. As the college leaders, they only orally agree upon the importance of ideological and political education, while in the current action, they only respond to a variety of checks, without understanding the substantial role played by the ideological and political education to the development of college students. There are severe challenges facing our current evaluation system of ideological and political education, which are in need of being solved.

\section{The Innovative Ideas and Measures of College Ideological and Political Education in New Era}

From the current situation, there are still many problems about our ideological and political education in colleges, such as the updating of educational content and method is not timely, the overall quality of the education team is rather low, and the evaluation about the ideological and political education is not perfect. In the later educational process, it is essential to constantly improve the level of education teams and education evaluation system by means of innovative methods, with the purpose to achieve the goals of the ideological and political education in new era.

\subsection{Changing of the Concept of Ideological and Political Education}

The change of the concept of ideological and political education is mainly reflected in the following aspects. First, we must rationally analyze the reality of the ideological and political education, continue to implement the scientific concept of development, fully develop the human-centered ideas, and make full use of the idea into ideological and political education, in order to make the ideological and political education transfer from the previous school-centered, and teacher-centered education into a student-centered education. Students should be put as an important factor of the ideological and political education, and thus to realize the concept of "students' interests oriented". Second, students should be considered as ideological and political education, and a "Student-oriented" concept ought to be established. Third, students should become the heart of the practice of ideological and political education so as to achieve the concept of "training of personnel with the practice". Fourth, students need to play the role of the creative source of ideological and political education, to realize such ideas and goals of the innovation of values. Fifth, students should be treated as the central value of ideological and political education, with the purpose to make ideological and political education eventually become mass-oriented, scientific, and technological achievements to some extent.

\subsection{Innovative Methods of Ideological and Political Education}

As to the innovative methods of ideological and political education, there are mainly four points. Firstly, it is urgent to change the backward unilateral injective teaching into heuristic model of education to meet the needs of the moment. Discussion-style education should be introduced with the purpose to make the communication and talk between teachers and students free, to make them study the issues together, to propose a solution, and to get their enthusiasm and initiative 
fully motivated. Through continuous communication between each other, the class may be alive, and students' learning interest and desire for knowledge may be stimulated. A variety of teaching methods can be used, including listening to the lectures, readings books, journals and other relative materials, etc.. To be brief, different kinds of forms, methods, and social resources should be fully used to promote the students' enthusiasm and initiative.

Secondly, the traditional teaching model should be got rid of. In the teaching process of the ideological and political theory, such actions should be taken as community activities, public service activities and social behavior of the times, in order to create a free, authentic and diversified teaching model, in which the students feel pleasure, absorb the knowledge consciously as a hobby and thus lay the foundation for a virtuous cycle of ideological and political learning for the future. When the teaching results are to be checked, open-book exam and social practice can be used and it is no need for the educators to confine to the traditional paper quiz and scores to determine the students' ideological and political level. In this way, the theory and practice of ideological and political education are able to achieve the combination targets.

Thirdly, it is necessary to take full advantage of the Internet and continue to build an excellent education base. It is known to us all that the Internet is a sword blade, while bringing a lot of convenience to people's lives, it has also brought a series of negative effects. It is an effective and timely way to take advantage of the sound, safe, and effective Internet to the ideological and political education. When establishing the campus network, colleges can put up the dynamic news timely through which students are able to learn about the latest situation of the colleges, and colleges can also provide an activity area for students to do extracurricular activities and to be actively involved in charity. In addition, the national policy about ideological and political education, as well as those positive factors in the society can be published, so that students feel the positive impact and positive energy transferred. Moreover, message boards and forums can be set up to enable students to present their opinions directly to the colleges, and the colleges can respond at their earliest convenience, by which the communication between the students and the colleges will be increased. In the forums, students can communicate freely between each other, and can communicate as a team, to provide a platform for other students to improve ideas. Through the network of propaganda, it is possible to constantly enrich the ideological and political education, to motivate the initiative of the students as well as possible, and to make it the center of ideological and political education, meanwhile, the colleges are able to easily grasp the initiative in ideological and political education to effectively prevent bad information impact on student thinking.

Fourthly, in the ideological and political education, psychological education plays an important role. With a complex social environment, more temptations are in front of the students and more tremendous pressure is waiting for the students. If you cannot provide a good psychological education and ease students' knot in time, it is likely to cause their mental illness, impossible to talk about the ideological and political education.

Therefore, the mental health education of college students has to be enhanced from the following two aspects. On the one hand, it is a necessity to set up mental health institutions for college students, equipped with a high level of political and ideological education team, overall arranged and planned by various special staff, with the purpose to conduce a good mental health education all over the college. On the other hand, a comprehensive mental health guidance should be carried out from the freshmen. Each college student should have a psychological test with scientific methods and those who have problems should be identified and given corresponding counseling, so as to promote their physical and mental growth.

\subsection{Strengthening the Construction of Ideo- logical and Political Education Team}

In the course of ideological and political education, college students are the most massive body, and the corresponding maximum dominant body is the education team. Therefore, this education team is in relation to the level of ideological and political education and it is an inevitable condition of improving college students' ideology. The overall quality of the education team is a key factor. Only when both of the two participants of the ideological and political education maintain a high level, can the entire higher education outcomes be ensured. In order to vigorously promote the management level of ideological and political education team, a sound management mechanism must be made out. At the mean time, it is crucial to strive to build a strong political teaching staff with refined operational capacity and rigorous style. Under the mutual cooperation of the two parts, it is possible to build a perfect ideological and political education team.

\subsection{Promotion of Community Education}

There is no fixed classrooms for students to study in, and colleges often implement credit management methods, therefore, dormitory become a resident place for the college students. Generally speaking, the majority of college students spend their spare time in the dormitory, as a result, the dormitory bear such features as relatively concentrated staff, rapid transmission of information, and stable personnel. So, during the administration, colleges can consider the dormitory as a basic element. Being the most relaxing, most liberal and ideas pooling place, dormitory is a natural entry point of ideological and political education.

On the one hand, when doing the management of students' life, colleges can make dorm life become socialized, however, there should not be a lack of moral education for college students. Students' moral education ought to be fully in place, and students' caucus organization should be extensively expanded.

On the other hand, as a direction of college moral education, students' community plays a considerable role. Through various organizations, community can 
initiate various forms activities of ideological and political education, which can not only enrich students' extracurricular life, but also activate students' thinking, as these community activities are innovative and easily accepted. Therefore, the college communities are able to play a good effect to spread ideological and political education, of which colleges should take advantage to strengthen ideological and political education of the community.

\section{Conclusion}

In summary, the development of the ideological and political education in new era plays a very important role in cultivating the view of the world, life and values of college students. Facing the construction of the ideological and political education, it is time to change the traditional concept and to constantly develop the modern and practical value concept. It is important to take advantage of the Internet to build campus network, the information of which should be managed by laws and regulations, with the purpose to prompt students to form correct ideas. Great importance must be attached to psychological education, as mental health education is the key point to improve the ideological and political education. Flexible ways ought to be adopted to learn about the students' mental activity, to discover students' psychological problems. Based on this, psychological education system should be constantly improved, so that students have a long-term mechanism of psychological education and achieve the mental health.

\section{References}

[1] Richard Pring. Education as a Moral Practice. The Journal of Moral Education . 2001

[2] Tsutsui, William M. Manufacturing Ideality: Scientific Management in Twentieth Century Japan. 1998

[3] Hong Junhao. The Internationalization of Television in China: the Evolution of Ideology, Society, and Media since the Reform. 1998 